\title{
CRM-1 knockdown inhibits extrahepatic cholangiocarcinoma tumor growth by blocking the nuclear export of p27 ${ }^{\text {Kip1 }}$
}

\author{
JIAN LUO ${ }^{1}$, YONGJUN CHEN ${ }^{2}$, QIANG LI ${ }^{3}$, BING WANG ${ }^{2}$, YANQIONG ZHOU ${ }^{1}$ and HONGZHEN LAN ${ }^{1}$ \\ Departments of ${ }^{1}$ Geriatrics, ${ }^{2}$ Bile Duct and Pancreatic Surgery, and ${ }^{3}$ Gynecology and Obstetrics, Tongji Hospital, \\ Tongji Medical College, Huazhong University of Science and Technology, Wuhan, Hubei 430030, P.R. China
}

Received August 27, 2015; Accepted May 18, 2016

DOI: $10.3892 / \mathrm{ijmm} .2016 .2628$

\begin{abstract}
Cholangiocarcinoma is a deadly disease which responds poorly to surgery and conventional chemotherapy or radiotherapy. Early diagnosis is difficult due to the anatomical and biological characteristics of cholangiocarcinoma. Cyclin-dependent kinase inhibitor $1 \mathrm{~B}\left(\mathrm{p} 27^{\mathrm{Kip} 1}\right)$ is a cyclin-dependent kinase inhibitor and in the present study, we found that $\mathrm{p} 27^{\mathrm{Kip} 1}$ expression was suppressed in the nucleus and increased in the cytoplasm in 53 samples of cholangiocarcinoma from patients with highly malignant tumors (poorly-differentiated and tumor-node-metastsis (TNM) stage III-IV) compared with that in samples from 10 patients with chronic cholangitis. The expression of phosphorylated (p-)p2 $7^{\mathrm{Kip} 1}$ (Ser10), one of the phosphorylated forms of $\mathrm{p} 27^{\mathrm{Kip} 1}$, was increased in the patient samples with increasing malignancy and clinical stage. Coincidentally, chromosome region maintenance 1 (CRM-1; also referred to as exportin 1 or Xpo1), a critical protein responsible for protein translocation from the nucleus to the cytoplasm, was also overexpressed in the tumor samples which were poorly differentiated and of a higher clinical stage. Through specific short hairpin RNA (shRNA)-mediated knockdown of CRM-1 in the cholangiocarcinoma cell line QBC939, we identified an elevation of cytoplasmic p27 $7^{\mathrm{Kip} 1}$ and a decrease of nuclear $\mathrm{p} 27^{\mathrm{Kip} 1}$. Furthermore, the viability and colony formation ability of QBC939 cells was largely reduced with G1 arrest. Consistent with the findings of the in vitro experiments, in a xenograft mouse model, the tumors formed in the CRM-1 knockdown group were markedly smaller and weighed less than those in the control group in vivo. Taken together, these findings demonstrated that the interplay between CRM-1 and p27 ${ }^{\mathrm{Kip} 1}$ may provide potentially potent biomarkers and functional targets for the development of future cholangiocarcinoma treatments.
\end{abstract}

Correspondence to: Dr Jian Luo, Department of Geriatrics, Tongji Hospital, Tongji Medical College, Huazhong University of Science and Technology, 1095 Jiefang Avenue, Wuhan, Hubei 430030, P.R. China

E-mail: luojian76@126.com

Key words: cholangiocarcinoma, p27 $7^{\mathrm{Kip} 1}$, chromosome region maintenance 1 , nucleocytoplasmic transport, phosphorylation

\section{Introduction}

Cholangiocarcinoma is a rare, gastrointestinal cancer which responds poorly to surgery and chemoradiotherapy and therefore has a poor long-term outcome. Early diagnosis is difficult due to the anatomical and biological characteristics of cholangiocarcinoma. Thus, the identification of molecular mechanisms underlying the carcinogenesis in cholangiocarcinoma is critical for the development of novel potent drugs and therapies.

Cyclin-dependent kinase inhibitor 1B (p27 $\left.{ }^{\mathrm{Kipl}}\right)$ is underexpressed and exhibits abnormal subcellular localization in the cytoplasm of some types of malignant tumors $(1,2)$. As mutations of $\mathrm{p} 27^{\mathrm{Kip} 1}$ are rare, this has been attributed to the post-transcriptional regulation of nucleocytoplasmic transport as well as the nuclear-cytoplasmic distribution of p2 $7^{\text {Kipl }}$ (3). p2 $7^{\mathrm{Kip} 1}$ is transported through nuclear pore complexes within the nuclear membrane and is transferred either into or out of the nuclei by specific carriers, mediated by nuclear localization signals (4). The aberrant expression and cytoplasmic detention of $\mathrm{p} 27^{\mathrm{Kip} 1}$ involves an increase in proteolysis, which correlates with the nuclear export and import of $\mathrm{p} 27^{\mathrm{Kip1}}$, and leads to its abnormal localization outside the nuclei. However, the mechanisms responsible for the nucleocytoplasmic transport of $\mathrm{p} 27^{\mathrm{Kipl}}$ remain poorly understood.

The nuclear export factor, chromosome region maintenance 1 (CRM-1; also referred to as exportin 1 or Xpol) plays a key role in the nuclear export of proteins that have a nuclear export signal sequence in eukaryotic cells. Previous research has shown that CRM-1 closely correlates with the nuclear export and import of the $\mathrm{p} 27^{\mathrm{Kip} 1}$-encoded protein, which in turn is closely associated with the phosphorylation of Ser10, to produce phosphorylated (p-)p27 ${ }^{\text {Kipl }}$ (Ser10) (5). The nuclear export factor Jab1 facilitates the CRM-1-mediated export of $\mathrm{p} 27^{\mathrm{Kip} 1}$ by specifically recognizing and binding to p-p27 $7^{\text {Kipl }}$ (Ser10) (3). However, studies regarding the association between CRM-1, p27 $7^{\mathrm{Kip} 1}$ and p-p27 ${ }^{\mathrm{Kip}}$ (Ser10) in human cholangiocarcinoma are limited.

In the present study, we examined the expression patterns of CRM-1 and $\mathrm{p} 27^{\mathrm{Kip} 1}$ proteins, and the phosphorylation of p27 ${ }^{\text {Kipl }}$ (Ser10) in cholangiocarcinoma tissues compared with that in chronic cholangitis tissues. We aimed to examine the roles of CRM-1 in the nucleocytoplasmic transport of $\mathrm{p} 27^{\mathrm{Kipl}}$ and in the development and progression of human cholangiocarcinoma. 


\section{Materials and methods}

Ethics statement. The present study was approved by the Ethics Committee of Tongji Hospital [Tongji Medical College, Huazhong University of Science and Technology (HUST), Wuhan, China]. All the mice in our experiment were housed in the SPF Animal Center at Tongji Medical College (HUST, Wuhan, China). All mice were underwent general anesthesia which was induced with isoflurane inhalation prior to sacrifice (mice were euthanized in a box filled with $\mathrm{CO}_{2}$ followed by cervical dislocation) in order to minimize their suffering. Written consent was obtained from all patients before enrollment. The present study complied with the principles that govern the use of human tissues as outlined in the Declaration of Helsinki.

Histological assessment. The extrahepatic cholangiocarcinoma tissue samples were classified into perihilar (or proximal) and middle or distal subgroups, according to their anatomic location along the biliary tree (6,7). Clinical staging was based on the tumor-node-metastasis (TNM) classification system defined by the American Joint Committee on Cancer (AJCC) and the Union for International Cancer Control (UICC). The TNM classification in extrahepatic cholangiocarcinoma mainly includes perihilar bile duct carcinoma and distal bile duct carcinoma. The TNM staging and grading of perihilar bile duct carcinoma has been summarized by Ganeshan et al (6).

Study population and specimen collection. The tumor tissue specimens were collected from 53 patients with extrahepatic cholangiocarcinoma and 10 patients with chronic proliferative cholangitis as a control group. The patients all underwent surgery at the Department of General Surgery at Tongji Hospital (Tongji Medical College, HUST, Wuhan, China) between 2008 and 2010. None of the patients had undergone preoperative treatment, such as radiotherapy or chemotherapy. The clinicopathological details of the patients, including gender, age, tumor diameter, histological subtype, tumor location, tumor grade and clinical TNM stage were accessed from the hospital database. The mean and median ages of the cholangiocarcinoma patients were 51.5 and 45.0 years, respectively (range, $33-75$ years) and the male:female ratio was 1.3:1 (30 males; 23 females). The locations of the lesions in the bile duct were as follows: 16/53 (30.2\%) proximal; 14/53 (26.4\%) middle; and 23/53 (43.4\%) distal. These included 24/53 (45.3\%) well-differentiated, 12/53 (22.6\%) moderately-differentiated and 17/53 (32.1\%) poorly-differentiated adenocarcinomas. There were 22/53 (41.5\%) patients in stages I-II, and 31/53 (58.5\%) patients in stages III-IV.

Antibodies, plasmids and reagents. p27 $^{\mathrm{Kip} 1}$ (ZA-0557) mouse anti-human monoclonal antibody, horseradish peroxidase (HRP)-labeled goat-anti-mouse IgG (ZB-2301), streptavidin-peroxidase (SP) immunostaining kit and 3,3'-diaminobenzidine (DAB) were purchased from Beijing Zhongshan Golden Bridge Biotechnology Co., Ltd. (Beijing, China); rabbit anti-CRM-1 (H-300; sc-5595), p-p27 ${ }^{\text {Kipl }}$ (Ser10; sc-12939-R), proliferating cell nuclear antigen (PCNA; sc-7907) and GAPDH (FL-335) were purchased from Santa Cruz Biotechnology (Santa Cruz, CA, USA). The electrochemiluminescence (ECL) reagents were purchased from Pierce Chemical Co. (Rockford, IL, USA). We constructed two specific short hairpin RNAs (shRNAs) using a pSicoR vector bought from Addgene (Cambridge, MA, USA) targeting CRM-1 as previously describd by Wang et al (8) and the corresponding shRNA sequences were as follows: shRNA1, GAAGTACTGACACATTTAA; and shRNA2, GGCTGCTGAACTCTATAGA. The data shown in Figs. 4,5 and 6 are from shRNA1 (shCRM-1) and the results from shRNA2 targeting CRM-1 were generally the same as those from shRNA1 (data not shown).

Immunostaining. The tissue specimens were fixed in $10 \%$ formalin and embedded in paraffin prior to sectioning into $3 \mu \mathrm{m}$ slices and stained with hematoxylin and eosin (H\&E). The sections were pathologically diagnosed by two independent, double-blind pathologists (Z. Hongbo and D. Hao). The tissue sections were deparaffinized, washed in phosphate-buffered saline (PBS) and prepared for immunohistochemistry according to the SP protocol. Briefly, antigen retrieval was performed using a microwave, and endogenous peroxidase activity was blocked with $0.3 \% \mathrm{H}_{2} \mathrm{O}_{2}$ and non-specific reactions were blocked with normal goat serum. The samples were incubated with the primary antibody overnight at $4^{\circ} \mathrm{C}$, followed by incubation with biotinylated secondary antibody and HRP-conjugated streptavidin. For the control group, the primary antibody was replaced with PBS; for the negative control group, the primary antibody was replaced with normal goat serum. Immunohistochemical (IHC) staining of the sections was followed by DAB staining and counterstaining with hematoxylin. The slides were dehydrated, and mounted.

A minimum of $1 \times 10^{3}$ cells were counted from 10 randomly selected fields (magnification, $\mathrm{x} 400$ ) for each section under a light microscope (1X71 inverted microscope; Olympus Corp., Tokyo, Japan). The proteins appearing brown or tan in the nuclei, the cytoplasm or both were defined as positive. The mean percentage of positive cells was calculated for each patient. The tissue samples were defined as having nuclear or cytoplasmic expression of a protein if $>25 \%$ of the cells showed positive staining in the nuclei or cytoplasm, respectively.

Isolation of cytoplasmic and nuclear proteins. The cytoplasmic and nuclear proteins were separated using the ProteoJET Cytoplasmic and Nuclear Protein Extraction kit (Fermentas International, Inc., Burlington, ON, Canada) according to the manufacturer's instructions. Briefly, the fresh tissue samples were rinsed with ice-cold PBS and blotted dry. The tissues were then gently homogenized in PBS with protease inhibitors. The homogenate was centrifuged in a microcentrifuge at $250 \mathrm{xg}$ for $5 \mathrm{~min}$ at $4^{\circ} \mathrm{C}$. The supernatant was discarded and $500 \mu \mathrm{l}$ of cell lysis buffer containing protease inhibitors and dithiothreitol (DTT) was added to $100 \mathrm{mg}$ tissue, mixed gently by vortexing, and set on ice for $10 \mathrm{~min}$. The cytoplasmic fraction was separated from the nuclei by centrifugation at $500 \mathrm{xg}$ for $7 \mathrm{~min}$ at $4^{\circ} \mathrm{C}$. The nuclear pellet was set on ice and the supernatant was centrifuged at $20,000 \mathrm{xg}$ for $15 \mathrm{~min}$ at $4^{\circ} \mathrm{C}$ to separate the cytoplasmic protein extract. This was then transferred to a new tube and either used immediately or stored at $-70^{\circ} \mathrm{C}$. The nuclear pellet was washed in $500 \mu \mathrm{l}$ nuclei washing buffer containing protease inhibitors and DTT by vortexing briefly, and then set on ice for $2 \mathrm{~min}$. The suspension was centrifuged at $500 \mathrm{xg}$ for $7 \mathrm{~min}$ at $4^{\circ} \mathrm{C}$, and the supernatant was carefully removed. This 
procedure was repeated 1-2 times. The volume of the nuclear pellet was estimated and 10 volumes of ice-cold nuclei storage buffer containing protease inhibitors and DTT were added. Any clumps of nuclei were broken up by gentle pipetting. The suspension was either used immediately or stored at $-70^{\circ} \mathrm{C}$. Following centrifugation at $20,000 \mathrm{x}$ g for $5 \mathrm{~min}, 150 \mu \mathrm{l}$ ice-cold nuclei storage buffer with protease inhibitors and DTT was added to the nuclear pellet. Any clumps were broken up as before. The nuclei were lysed by adding $1 / 10$ volume of nuclei lysis reagent to the suspension, vortexed briefly and shaken on a rotating bed (900-1,200 rpm) for $15 \mathrm{~min}$ at $4^{\circ} \mathrm{C}$. The resulting nuclear lysate was cleared by centrifugation at $20,000 \mathrm{x}$ g for $5 \mathrm{~min}$ at $4^{\circ} \mathrm{C}$, and the supernatant containing the nuclear protein extract was transferred to a new tube and either used immediately or stored at $-70^{\circ} \mathrm{C}$ for subsequent analysis.

Western blot analysis. Equivalent amounts of nuclear or cytoplasmic proteins were separated by SDS polyacrylamide gel electrophoresis. The proteins were electrolytically transferred to a PVDF membrane and blocked in TBST containing 20\% non-fat milk for $2 \mathrm{~h}$ at room temperature. The membrane was incubated at room temperature for $1 \mathrm{~h}$ with primary antibodies against $\mathrm{p} 27^{\mathrm{Kip} 1}$ (1:2,000); CRM-1 (1:1,000); and p-p27 ${ }^{\mathrm{Kip} 1}$ (Ser10) (1:1,000). After further incubation overnight at $4^{\circ} \mathrm{C}$, the membrane was incubated with HRP-conjugated secondary antibodies $(1: 1,000)$ for $2 \mathrm{~h}$ at room temperature. The protein bands were developed by ECL and exposed to X-ray film. The intensities of the protein bands were quantified using a grayscale scanner (GeneGnome XRQ; Syngene Corp., Cambridge, UK). PCNA $(1: 2,000)$ and GAPDH $(1: 5,000)$ were used as loading controls.

Cell viability assay. The cholangiocarcinoma cell line QBC939 (kindly donated by Professor Shu-Guang Wang, Hepatobiliary Department of Xinan Hospital, Third Military Medical University, Chongqing, China) was infected with lentivirus encoding shCRM-1 or the vector (psicoR plasmid) after lentivirus packaging for approximately $24 \mathrm{~h}$. Following treatment, the above two groups together with untreated QBC939 cells (blank group) were transferred to 96-well plates at a density of 1,000 cells/well. Cell viability was evaluated using a Cell Counting Kit-8 (CCK-8) assay (Promoter, Wuhan, China) and a 5-ethynyl-2'-deoxyuridine (EdU) assay (Guangzhou RiboBio Co., Ltd., Guangzhou, China) according to the manufacturer's instructions.

Colony formation assay. Exponentially proliferating QBC939 cells treated as described above were seeded at a density of approximately 1,000 cells/well in a 6-well plate and the media was replaced every 3 days. The colonies were counted and evaluated after 10 days by staining with $0.05 \%$ crystal violet solution (C8470; Solarbio Corp., Beijing, China) for $15 \mathrm{~min}$.

Cell cycle analysis. Exponentially proliferating QBC939 cells stably transfected with either lenti-vector or lenti-shCRM-1 were counted after digestion with EDTA-free trypsin and rinsed with $\mathrm{PBS}$ followed by fixation in $70 \%$ precooled ethanol at $4^{\circ} \mathrm{C}$ overnight. After incubation with RNase A (Sigma, St. Louis, MO, USA) at $37^{\circ} \mathrm{C}$ for $30 \mathrm{~min}$, the cells were stained with propidium iodide (PI; KeyGen Biotech, Nanjing, China) at $4^{\circ} \mathrm{C}$ for $30 \mathrm{~min}$. The cells were then analyzed by flow cytometry (BD Biosciences, Franklin Lakes, NJ, USA) to measure the proportion of cells in the G1, S and G2/M stages.

Xenograft tumor growth assay. The in vivo tumorigenicity of cholangiocarcinoma cells was determined by subcutaneously injecting $1 \times 10^{6}$ cancer cells per mouse into the left axillary fossa of the nude BALB/cA-nu mice (purchased from HFK Bioscience Corp., Beijing, China). The 3 groups of nude mice ( 5 mice/group) were injected with either shCRM-1, the vector or blank cells. Tumor volume was measured with calipers at the same site of injection every 3 days by two trained laboratory staff at different times on the same day starting from the 15 th day using the formula, $\mathrm{V}=0.5 \mathrm{ab}^{2}$, in which ' $\mathrm{a}$ ' stands for the longer axis and ' $b$ ' stands for the shorter axis of the tumor. The animals were sacrificed and the tumors were weighed 60 days after injection. The nude mice were sacrificed and cared for according to the NIH Animal Care and Use Committee guidelines of the Experimental Animal Center of Tongji Medical School (HUST, Wuhan, China).

Statistical analysis. Statistical analyses were performed using SPSS software v. 20.0 (SPSS, Inc., Chicago, IL, USA). Fisher's exact test was used to determine significant differences between groups of data, the Chi-square $\left(\chi^{2}\right)$ test was used to compare protein expression percentages and Spearman's rank correlation test was used to compare pairs of variables. All values are presented as the means \pm SEM unless otherwise indicated and the t-test was adopted to examine the difference between the CRM-1 knockdown group, blank group and vector group. $\mathrm{P}<0.05$ was considered to indicate a statistically significant difference.

\section{Results}

Expression patterns of CRM-1, p2 $7^{\text {Kipl }}$ and p-p27 $7^{\text {Kipl }}$ (Ser10) proteins in cholangiocarcinoma tissues. In order to examine the role of CRM-1, p27 ${ }^{\mathrm{Kip} 1}$ and p-p27 ${ }^{\mathrm{Kip} 1}$ (Ser10) in the development of cholangiocarcinoma, we analyzed 53 cholangiocarcinoma tissue samples and 10 control chronic cholangitis samples using immunohistochemistry. The protein expression of CRM-1 and p-p27 ${ }^{\mathrm{Kip} 1}$ (Ser10) was significantly higher in the cholangiocarcinoma tissues compared with that in the control tissues (71.7 vs. $0.0 \%$ and 60.4 vs. $20.0 \%$, respectively; $\mathrm{P}<0.05$; Table I). By contrast, $\mathrm{p} 27^{\mathrm{Kip} 1}$ expression was significantly lower in the cholangiocarcinoma tissues compared with that in the control tissues (37.7 vs. $80.0 \%$; $\mathrm{P}<0.05$; Table I). These results were supported by correlation analyses which showed that there was a negative correlation between the expression of CRM-1 and p-p2 $7^{\mathrm{Kip} 1}$ (Ser10) proteins and the expression of $\mathrm{p} 27^{\mathrm{Kip} 1}$ (correlation coefficients, $r=-0.461$ and $r=-0.484$, respectively; $\mathrm{P}<0.01$; Table II); whereas CRM-1 expression positively correlated with p-p27 ${ }^{\mathrm{Kip} 1}$ (Ser10) expression.

Correlations between $p 27^{\text {Kipl }}$, CRM-1, p-p27 $7^{\text {Kipl }}$ (Ser10) protein expression and clinicopathological features in cholangiocarcinoma. The correlations between the expression of CRM-1, p2 $7^{\mathrm{Kip} 1}$ and p-p2 $7^{\mathrm{Kip} 1}$ (Ser10) proteins and clinicopathological features in cholangiocarcinoma tissues are summarized in Table III. The results revealed that the expression of all three proteins significantly correlated with the tumor grade and clinical stage in cholangiocarcinoma $(\mathrm{P}<0.05$; Table III). 
Table I. Immunohistochemical analysis of p27 ${ }^{\mathrm{Kip} 1}, \mathrm{CRM}-1$ and p-p27 $7^{\mathrm{Kip} 1}$ (Ser10) protein expression in cholangiocarcinoma $(\mathrm{n}=53)$ and chronic proliferative cholangitis tissue samples $(\mathrm{n}=10)$.

\begin{tabular}{|c|c|c|c|c|c|c|c|c|c|}
\hline \multirow{2}{*}{$\begin{array}{l}\text { Tissue } \\
\text { samples }\end{array}$} & \multicolumn{2}{|c|}{$\mathrm{p} 27^{\mathrm{Kipl}} \mathrm{n}(\%)$} & \multirow[b]{2}{*}{ P-value } & \multicolumn{2}{|c|}{ CRM-1 n (\%) } & \multirow[b]{2}{*}{ P-value } & \multicolumn{2}{|c|}{$\begin{array}{c}\text { p-p27 } 7^{\mathrm{Kip} 1}(\operatorname{Ser} 10) \\
\mathrm{n}(\%)\end{array}$} & \multirow[b]{2}{*}{ P-value } \\
\hline & + & - & & + & - & & + & - & \\
\hline $\mathrm{CCA}(\mathrm{n}=53)$ & $20(37.7)$ & $33(62.3)$ & 0.034 & 38 (71.7) & $15(28.3)$ & 0.013 & $32(60.4)$ & 21 (39.6) & 0.035 \\
\hline $\mathrm{CPC}(\mathrm{n}=10)$ & $8(80.0)$ & $2(20.0)$ & & $0(0)$ & $10(100)$ & & $2(20.0)$ & $8(80.0)$ & \\
\hline
\end{tabular}

CCA, cholangiocarcinoma; $\mathrm{CPC}$, chronic proliferative cholangitis; $\mathrm{n}$, total number of positively (+) or negatively (-) stained cells in the samples (both nuclear and cytoplasmic); p-p27Kip1 (Ser10), phosphorylated p27Kip1 (Ser10); CRM-1, chromosome region maintenance 1. P-values in bold denote statistically significant differences $(\mathrm{P}<0.05)$.

Table II. Correlations between the expression of $\mathrm{p} 27^{\mathrm{Kip} 1}$ and CRM-1 and p-p27 $7^{\text {Kip1 } 1}$ (Ser10) expression in cholangiocarcinoma tissue samples $(\mathrm{n}=53)$.

\begin{tabular}{|c|c|c|c|c|c|c|}
\hline & \multicolumn{2}{|c|}{ CRM-1 n } & \multirow[b]{2}{*}{ r-value } & \multicolumn{2}{|c|}{$\begin{array}{l}\text { p-p27 }{ }^{\text {Kip1 }} \\
(\text { Ser10) n }\end{array}$} & \multirow[b]{2}{*}{ r-value } \\
\hline & + & - & & + & - & \\
\hline \multicolumn{7}{|c|}{$\mathrm{p} 27^{\mathrm{Kip} 1}$} \\
\hline+ & 9 & 11 & $-0.461^{\mathrm{a}}$ & 6 & 14 & $-0.484^{\mathrm{a}}$ \\
\hline - & 29 & 4 & & 26 & 7 & \\
\hline
\end{tabular}

Protein expression levels were evaluated by immunohistochemistry. Statistical analyses were performed by Spearman's rank correlation; r-value, correlation coefficient. ${ }^{\mathrm{a}} \mathrm{P}<0.05$; $\mathrm{p}-\mathrm{p} 27^{\mathrm{Kip} 1}$ (Ser10), phosphorylated $\mathrm{p} 27^{\mathrm{Kip} 1}$ (Ser10); CRM-1, chromosome region maintenance 1.

By contrast, there were no significant correlations between protein expression and patient age, gender, tumor size or site $(\mathrm{P}>0.05$; Table III). The expression of CRM-1 and p-p2 $7^{\text {Kip1 }}$ (Ser10) positively correlated with the degree of malignancy and clinical stage whereas the expression of $\mathrm{p} 27^{\mathrm{Kipl}}$ decreased with the degree of malignancy and clinical stage.

Associations between the subcellular localization of CRM-1, $p 27^{K i p l}$ and $p-p 27^{K i p l}$ (Ser10) with clinicopathological features in cholangiocarcinoma. The subcellular distributions of CRM-1, p27 ${ }^{\mathrm{Kip} 1}$ and p-p27 $7^{\mathrm{Kip} 1}$ (Ser10) proteins in cholangiocarcinoma tissues were examined by IHC analysis (Fig. 1). The staining patterns revealed that $\mathrm{p} 27^{\mathrm{Kipl}}$ was principally localized in the nuclei in chronic cholangitis tissue samples and was primarily localized in the nuclei, with little cytoplasmic staining in the cholangiocarcinoma tissues of low malignant potential (well-differentiated and TNM stage I-II); and was diffusely distributed in the nuclei and cytoplasm in the tissues of highly malignant tumors (poorly-differentiated and TNM stage III-IV). Evaluation of the IHC staining signals showed that the expression of cytoplasmic p27 $7^{\mathrm{Kipl}}$ increased from $12.5 \%$ (3/24) in well-differentiated tumors to $17.6 \%$ (3/17) in poorly-differentiated tumors; whereas the corresponding expression of nuclear p2 $7^{\text {Kipl }}$ decreased from $45.8 \%$ (11/24) to $0.0 \%$ (0/17). These changes were significant $(\mathrm{P}<0.05$; Table IV). A similar pattern was observed between the subcellular expression levels of p2 $7^{\mathrm{Kipl}}$ and the clinical stage of cholangiocarcinoma.

These results suggested that $\mathrm{p} 27^{\mathrm{Kipl}}$ may be transported from the nucleus to the cytoplasm, and that this is associated with increasing malignancy in cholangiocarcinoma. This further suggested that the nuclear export of $\mathrm{p} 27^{\mathrm{Kip} 1}$ may contribute to the progression and malignant transformation of cholangiocarcinoma.

By contrast, the IHC staining patterns revealed that the levels of nuclear CRM-1 and p-p27 ${ }^{\text {Kipl }}$ (Ser10) proteins were low in the chronic cholangitis tissue samples; however, the levels increased with increasing malignancy and clinical stage in the cholangiocarcinoma tissue samples. There was no significant change in their cytoplasmic levels ( $\mathrm{P}>0.05$; Table IV).

These results demonstrated that the cytoplasmic distribution of $\mathrm{p} 27^{\mathrm{Kipl}}$ was consistent with the cytoplasmic expression of CRM-1 and p-p27 Kipl (Ser10) (Fig. 3), suggesting that the involvement of $\mathrm{p} 27^{\mathrm{Kip} 1}$ nuclear export mediated by CRM-1 in the development and progression of cholangiocarcinoma. It suggested that CRM-1 and p-p27 ${ }^{\mathrm{Kipl}}$ (Ser10) may be implicated in the nuclear export of $\mathrm{p} 27^{\mathrm{Kipl}}$ during the development and progression of cholangiocarcinoma.

Furthermore, semi-quantitative western blot analysis and grayscale analysis were performed in order to confirm the results of IHC staining by evaluating the protein concentrations of p27 $7^{\mathrm{Kip} 1}, \mathrm{CRM}-1$ and p-p27 ${ }^{\mathrm{Kip} 1}$ (Ser10) according to their subcellular localizations in the cholangiocarcinoma tissues (Tables V and VI). The results of the grayscale analysis revealed that the nuclear levels of CRM-1 protein as well as the phosphorylation of $\mathrm{p} 27^{\mathrm{Kipl}}$ (Ser10) increased with increasing malignancy and clinical stage in cholangiocarcinoma; whereas the opposite effect was observed for $\mathrm{p} 27^{\mathrm{Kipl}}$ (Table V; Fig. 2). However, there was little change in the cytoplasmic levels of CRM-1 protein and the phosphorylation of $\mathrm{p} 27^{\mathrm{Kipl}}$ (Ser10) with malignancy or clinical stage, and only a small increase in the cytoplasmic expression of p27 $7^{\mathrm{Kip} 1}$ (Table VI; Fig. 3). These results indicated that the subcellular distribution of $\mathrm{p} 27^{\mathrm{Kip} 1}$ protein was closely associated with its phosphorylation and the expression of CRM-1. These findings support the hypothesis that the nuclear export of $\mathrm{p} 27^{\mathrm{Kipl}}$ may be implicated in the progression and malignancy of cholangiocarcinoma.

Downregulation of CRM-1 inhibits the colony forming ability and reduces the viability of the cholangiocarcinoma cell line 
Table III. Correlations between the expression of $\mathrm{p} 27^{\mathrm{Kip} 1}, \mathrm{CRM}-1$ and p-p27 ${ }^{\mathrm{Kip} 1}$ (Ser10) proteins and clinicopathological features in cholangiocarcinoma tissue samples $(n=53)$.

\begin{tabular}{|c|c|c|c|c|c|c|c|}
\hline Variable & Total & $\begin{array}{l}\mathrm{p} 27^{\mathrm{Kip} 1} \\
\mathrm{n}(\%)\end{array}$ & P-value & $\begin{array}{l}\text { CRM-1 } \\
\text { n }(\%)\end{array}$ & P-value & $\begin{array}{c}\mathrm{p}-\mathrm{p} 27^{\mathrm{Kip} 1}(\operatorname{Ser} 10) \\
\mathrm{n}(\%)\end{array}$ & P-value \\
\hline Gender & 53 & & 0.779 & & 0.380 & & 1.000 \\
\hline Male & 30 & $12(40.0)$ & & $20(66.7)$ & & $18(60.0)$ & \\
\hline Female & 23 & $8(34.8)$ & & $18(78.3)$ & & $14(60.9)$ & \\
\hline Age (years) & 53 & & 1.000 & & 0.761 & & 1.000 \\
\hline$<60$ & 28 & $11(39.3)$ & & $21(75.0)$ & & $17(64.7)$ & \\
\hline$\geq 60$ & 25 & $9(36.0)$ & & $17(68.0)$ & & $15(60.0)$ & \\
\hline Size (cm) & 53 & & 0.773 & & 0.546 & & 0.397 \\
\hline$<2$ & 21 & $7(33.3)$ & & $14(66.7)$ & & $11(52.4)$ & \\
\hline$\geq 2$ & 32 & 13 (40.6) & & $24(75.0)$ & & $21(65.6)$ & \\
\hline Location & 53 & & 0.769 & & 0.929 & & 0.938 \\
\hline Proximal & 16 & $5(31.2)$ & & $11(68.75)$ & & $9(56.3)$ & \\
\hline Middle & 14 & $5(35.7)$ & & $10(71.43)$ & & $9(64.3)$ & \\
\hline Distal & 23 & $10(43.5)$ & & 17 (73.91) & & $14(60.9)$ & \\
\hline Grade & 53 & & 0.022 & & 0.048 & & 0.003 \\
\hline Well & 24 & $14(58.3)$ & & 13 (54.17) & & $10(41.67)$ & \\
\hline Moderate & 12 & $3(25.0)$ & & $10(83.33)$ & & $8(66.67)$ & \\
\hline Poor & 17 & 3 (17.6) & & 15 (88.24) & & $14(82.35)$ & \\
\hline Stage & 53 & & 0.010 & & 0.003 & & 0.023 \\
\hline I-II & 22 & $13(59.09)$ & & $12(54.55)$ & & $9(40.91)$ & \\
\hline III-IV & 31 & $7(22.58)$ & & $26(83.87)$ & & $23(74.19)$ & \\
\hline
\end{tabular}

Protein expression levels were evaluated by immunohistochemistry.n, number of positively-stained samples in each subset; stage, tumor-node-metastasis (TNM) classification; grade, tumor grade (well, well-differentiated; moderate, moderately-differentiated; poor, poorly-differentiated); p-p27Kip1 (Ser10), phosphorylated p27Kip1 (Ser10); CRM-1, chromosome region maintenance 1. P-values in bold denote statistically significant differences $(\mathrm{P}<0.05)$.

Table IV. Correlations between the subcellular localizations of $\mathrm{p} 27^{\mathrm{Kip} 1}, \mathrm{CRM}-1$ and p-p27 ${ }^{\mathrm{Kip} 1}$ (Ser10) proteins and the malignancy of tumors in patients with cholangiocarcinoma (n=53) (Fig. 1).

\begin{tabular}{|c|c|c|c|c|c|c|c|c|c|c|}
\hline \multirow[b]{2}{*}{ Variable } & \multirow[b]{2}{*}{ Total } & \multicolumn{2}{|c|}{$\begin{array}{c}\text { p2 } 7^{\mathrm{Kip} 1} \\
\text { (positive) }\end{array}$} & \multirow[b]{2}{*}{ P-value } & \multicolumn{2}{|c|}{$\begin{array}{c}\text { CRM-1 } \\
\text { (positive) }\end{array}$} & \multirow[b]{2}{*}{ P-value } & \multicolumn{2}{|c|}{$\begin{array}{c}\text { p-p27 } 7^{\text {Kip1 }} \\
\text { (Ser10) } \\
\text { (positive) }\end{array}$} & \multirow[b]{2}{*}{ P-value } \\
\hline & & $\mathrm{N}$ & $\mathrm{C}$ & & $\mathrm{N}$ & $\mathrm{C}$ & & $\mathrm{N}$ & $\mathrm{C}$ & \\
\hline Grade & 53 & & & 0.018 & & & 0.851 & & & 0.583 \\
\hline Well & 24 & 11 & 3 & & 7 & 1 & & 8 & 2 & \\
\hline Moderate & 12 & 1 & 2 & & 5 & 2 & & 8 & 1 & \\
\hline Poor & 17 & 0 & 3 & & 10 & 3 & & 9 & 4 & \\
\hline Stage & 53 & & & 0.017 & & & 1.000 & & & 1.000 \\
\hline I-II & 22 & 10 & 3 & & 6 & 1 & & 11 & 2 & \\
\hline III-IV & 31 & 1 & 6 & & 17 & 4 & & 15 & 4 & \\
\hline
\end{tabular}

QBC939 both in vitro and in vivo. To explore the causal relationship between the downregulation of CRM-1 and the nuclear export of p27 ${ }^{\mathrm{Kip} 1}$ and carcinogenesis in cholangiocarcinoma, a classical cholangiocarcinoma cell line QBC939 was selected 


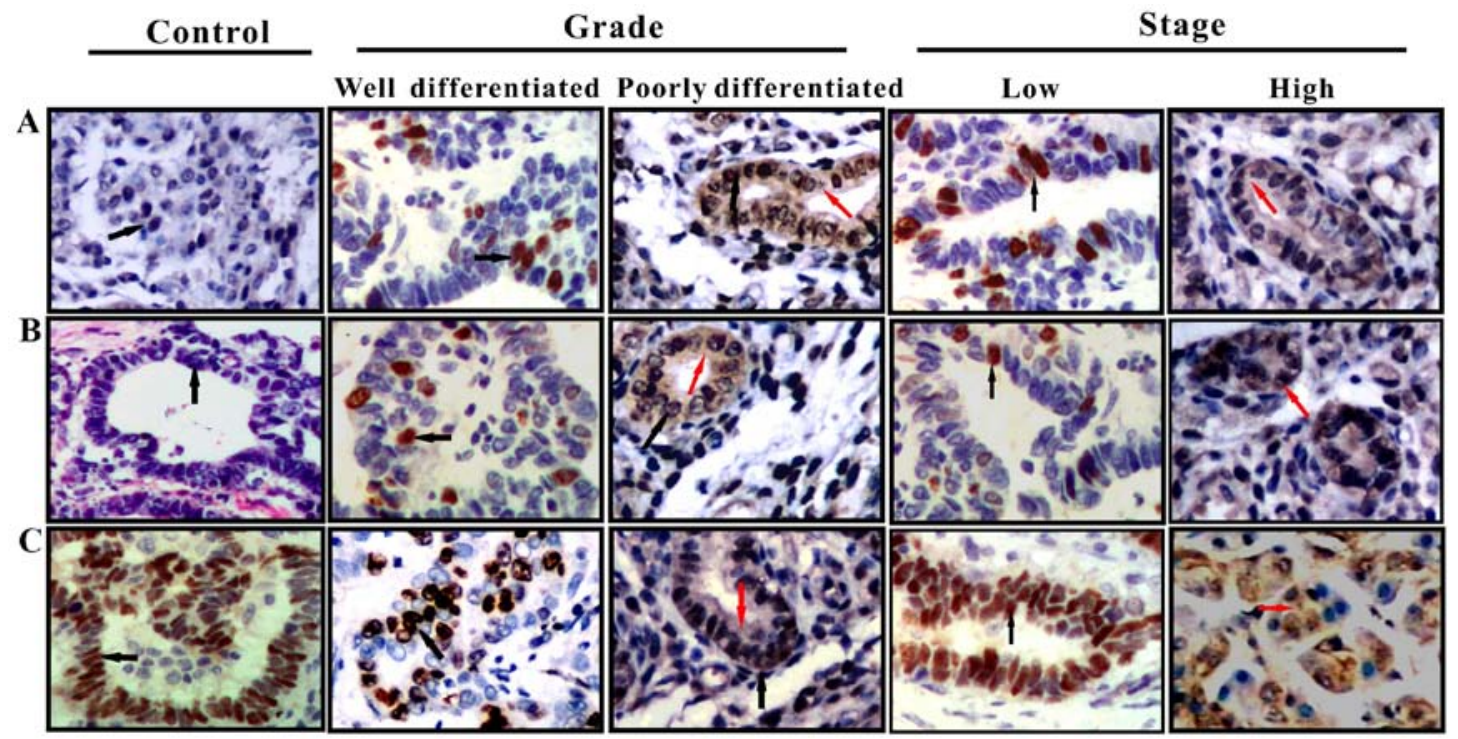

Figure 1. Immunohistochemical (IHC) analysis of the subcellular distribution and expression of chromosome region maintenance 1 (CRM-1), phosphorylated (p-)p2 $7^{\mathrm{Kipl}}$ (Ser10) and p-p27 $7^{\mathrm{Kipl}}$ proteins in cholangiocarcinoma and chronic cholangitis tissue samples. Corresponding data is shown in Table IV. The IHC images show positive nuclear (black arrows) and cytoplasmic (red arrows) expression of the proteins as brown and tan staining. Representative images show that (A) CRM-1 and (B) p-p27 ${ }^{\mathrm{Kipl}}$ (Ser10) are barely expressed in the chronic cholangitis tissue samples (control), and are mainly localized in the nuclei of well-differentiated cells and TNM stage I-II tissue samples, with little staining in the cytoplasm. However, both nuclear and cytoplasmic expression of CRM-1 and p-p2 $7^{\mathrm{Kipl}}$ (Ser10) are increased in the poorly-differentiated cells and TNM stage III-IV tumors. (C) By contrast, p2 $7^{\mathrm{Kipl}}$ protein is solely localized in the nuclei in chronic cholangitis tissue samples. However, cytoplasmic staining of p27 $7^{\mathrm{Kipl}}$ increases and nuclear expression decreases with increasing malignancy, suggesting that $\mathrm{p} 27^{\mathrm{Kip1}}$ is transported from the nuclei to cytoplasm during tumorigenesis in cholangiocarcinoma (magnification, $\mathrm{x} 400$ ).

Table V. Associations between nuclear expression of p2 $7^{\text {Kip1 }}$, CRM-1 and p-p27 ${ }^{\text {Kip1 }}$ (Ser10) proteins with different tumor grades and clinical stages in 53 cholangiocarcinoma tissues samples relative to 10 chronic cholangitis control samples (Fig. 2).

\begin{tabular}{|c|c|c|c|c|c|c|}
\hline \multirow[b]{2}{*}{ Protein } & \multirow[b]{2}{*}{ Control } & \multicolumn{3}{|c|}{ Grade (differentiation) } & \multicolumn{2}{|c|}{ Stage } \\
\hline & & Well & Moderate & Poor & I-II & III-IV \\
\hline $\mathrm{p} 27^{\mathrm{Kip} 1}$ & 1.0 & $0.91 \pm 0.17$ & $0.5 \pm 0.11$ & $0.35 \pm 0.19$ & $0.84 \pm 0.15$ & $0.47 \pm 0.22$ \\
\hline CRM-1 & 1.0 & $1.69 \pm 0.31$ & $1.83 \pm 0.25$ & $2.45 \pm 0.34$ & $1.57 \pm 0.19$ & $1.98 \pm 0.27$ \\
\hline p-p27 Kip1 $(\operatorname{Ser} 10)$ & 1.0 & $1.24 \pm 0.19$ & $1.43 \pm 0.33$ & $1.76 \pm 0.27$ & $1.42 \pm 0.32$ & $1.58 \pm 0.24$ \\
\hline
\end{tabular}

Expression levels of the proteins were determined by grayscale analysis and western blot analysis. Stage, tumor-node-metastasis (TNM) classification; grade, tumor grade (well, well-differentiated; moderate, moderately-differentiated; poor, poorly-differentiated); control, chronic cholangitis tissue samples; p-p27 $7^{\text {Kip1 }}$ (Ser10), phosphorylated p27 ${ }^{\text {Kip1 }}$ (Ser10); CRM-1, chromosome region maintenance 1.

Table VI. Associations between the cytoplasmic expression of p27 $7^{\text {Kip1 }}$, CRM-1 and p-p27 $7^{\text {Kip1 }}$ (Ser10) proteins with different grades and clinical stages in 53 cholangiocarcinoma tissue samples relative to 10 chronic cholangitis control samples (Fig. 3).

\begin{tabular}{|c|c|c|c|c|c|c|}
\hline \multirow[b]{2}{*}{ Protein } & \multirow[b]{2}{*}{ Control } & \multicolumn{3}{|c|}{ Grade (differentiation) } & \multicolumn{2}{|c|}{ Stage } \\
\hline & & Well & Moderate & Poor & I-II & III-IV \\
\hline $\mathrm{p} 27^{\mathrm{Kip} 1}$ & 1.00 & $1.19 \pm 0.17$ & $1.59 \pm 0.20$ & $1.83 \pm 0.27$ & $1.34 \pm 0.19$ & $1.62 \pm 0.22$ \\
\hline CRM-1 & 1.00 & $1.29 \pm 0.11$ & $1.13 \pm 0.05$ & $1.49 \pm 0.16$ & $1.25 \pm 0.17$ & $1.39 \pm 0.26$ \\
\hline p-p27 Kip1 $($ Ser 10$)$ & 1.00 & $1.30 \pm 0.15$ & $1.13 \pm 0.07$ & $1.41 \pm 0.27$ & $1.26 \pm 0.12$ & $1.43 \pm 0.18$ \\
\hline
\end{tabular}

Expression levels of the proteins were determined by grayscale analysis and western blot analysis. Stage, tumor-node-metastasis (TNM) classification; grade, tumor grade (well, well-differentiated; moderate, moderately-differentiated; poor, poorly-differentiated); control, chronic cholangitis tissue samples; p-p2 $7^{\text {Kip1 }}$ (Ser10), phosphorylated p27 $7^{\text {Kip1 }}$ (Ser10); CRM-1, chromosome region maintenance 1.

for CRM-1 knockdown. Notably, the colony formation assay demonstrated that the colony forming ability of the QBC939 cells was significantly inhibited by the knockdown of CRM-1 as compared with that in the blank and vector groups (Fig. 4A). 
A

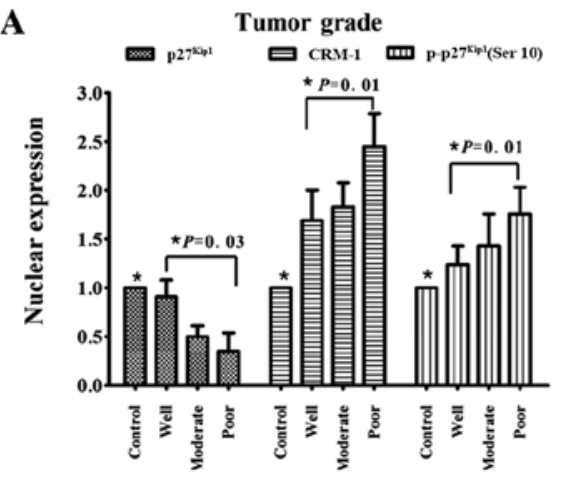

B

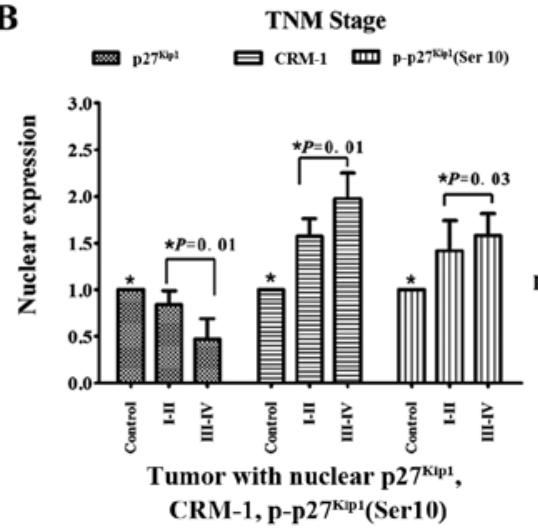

C

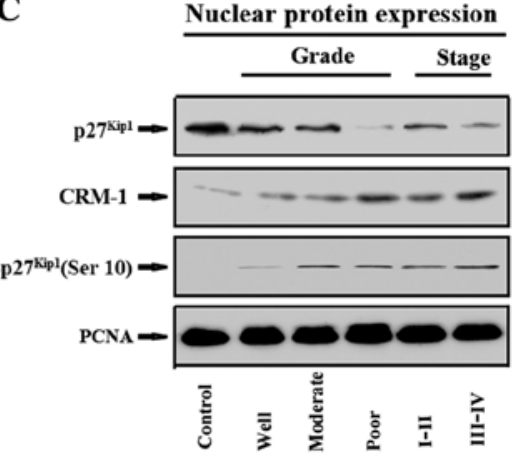

Figure 2. Western blot analysis and grayscale analysis of the nuclear expression of phosphorylated (p-)p27 $7^{\text {Kipl }}$, chromosome region maintenance 1 (CRM-1) and p-p2 $7^{\text {Kipl }}$ (Ser10) proteins in cholangiocarcinoma tissue samples. Corresponding data is shown in Table V. (A and B) Grayscale data showing the association between nuclear expression of the proteins with (A) tumor grade and (B) clinical tumor-node-metastasis (TNM) stage. The expression levels are shown relative to those in control chronic cholangitis tissue samples; ${ }^{*} \mathrm{P}<0.05$. (C) Western blots showing the intensities of the protein bands in the nuclear fractions of the cholangiocarcinoma tissue samples, according to tumor grade and clinical stage. Proliferating cell nuclear antigen (PCNA) was used as a loading control. The nuclear expression of CRM-1 and p-p27 $7^{\mathrm{Kip} 1}$ (Ser10) increased with increasing malignancy; whereas the nuclear expression of p27 ${ }^{\mathrm{Kip}}$ (Ser10) decreased with increasing malignancy. These data support the immunohistochemistry results in Fig. 1, which suggests that the transportation of p27 ${ }^{\mathrm{Kip} 1}$ from the nucleus to the cytoplasm is associated with increasing malignancy in cholangiocarcinoma. Well, well-differentiated; moderate, moderately-differentiated; poor, poorly-differentiated.
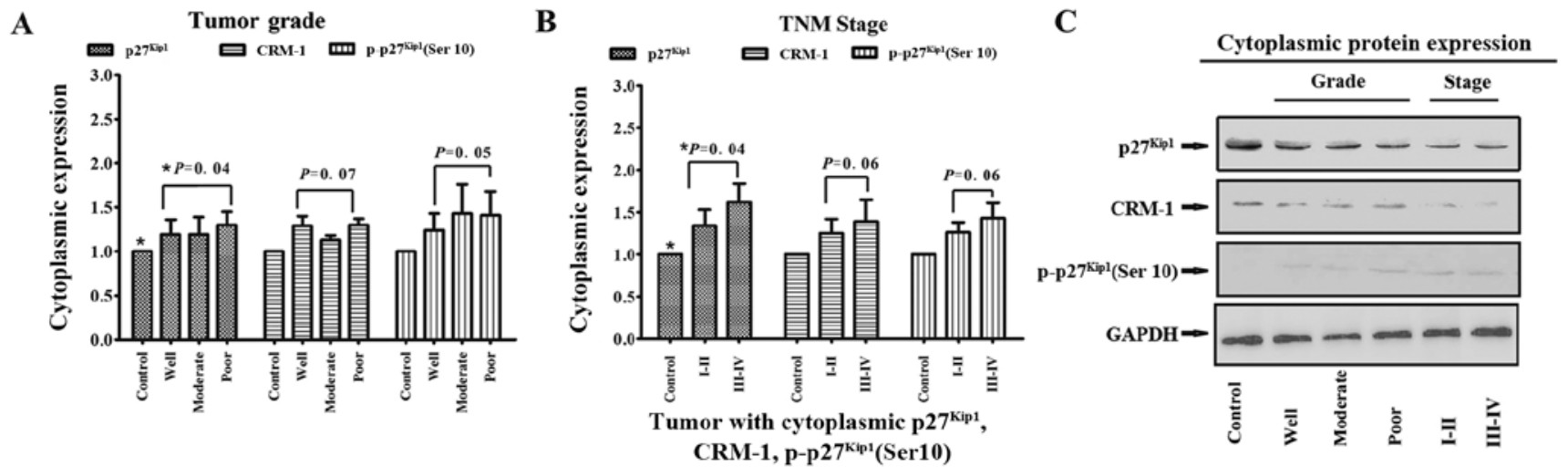

Figure 3. Western blot analysis and grayscale analysis of cytoplasmic expression of phosphorylated (p-)p27 ${ }^{\text {Kipl} 1}$, chromosome region maintenance 1 (CRM-1) and p-p27 ${ }^{\mathrm{Kip} 1}$ (Ser10) proteins in cholangiocarcinoma tissue samples. Corresponding data is shown in Table VI. Grayscale data showing the association between cytoplasmic protein expression with (A) tumor grade and (B) clinical tumor-node-metastasis (TNM) stage. The expression levels are shown relative to those in control chronic cholangitis tissue samples; ${ }^{*} \mathrm{P}<0.05$. (C) Western blots showing the intensities of the protein bands in the cytoplasm of cholangiocarcinoma tissue samples according to grade and clinical stage. GAPDH was used as a loading control. Cytoplasmic expression of CRM-1 and p-p27 ${ }^{\mathrm{Kip} 1}$ (Ser10) was not significantly changed by grade or clinical stage whereas the cytoplasmic expression of p27 ${ }^{\mathrm{Kipl}}$ increased with malignancy and clinical stage. These data are in accordance with the immunohistochemistry results in Fig. 1. Well, well-differentiated; moderate, moderately differentiated; poor, poorly differentiated.

Furthermore, the knockdown of CRM-1 by shRNA reduced the viability of QBC939 cells (Fig. 4B and C).

Additionally, performing the cell cycle analysis of these cells using the PI staining method, revealed marked G1 arrest in the QBC939-shCRM-1 group as compared with that in the blank and control groups (Fig. 4D).

Furthermore, in order to examine the precise role of CRM-1 in a xenograft mouse model, in vivo experiments were undertaken to evaluate the procarcinogenic effect of CRM-1 in cholangiocarcinoma. As shown in Fig. 5A, the CRM-1 knockdown group exhibited markedly smaller tumor volumes as compared with those in the blank and vector groups. The xenograft tumors were weighed and the CRM-1 knockdown group clearly produced lighter (Fig. 5B) and smaller tumors (Fig. 5C).

Downregulation of CRM-1 enhances nuclear $p 27^{\text {Kipl }}$ and decreases cytoplasmic p27 $7^{\text {Kipl }}$ simultaneously. In order to elucidate the underlying mechanism responsible for the pro-carcinogenic effect of CRM-1 in cholangiocarcinoma, nuclear and cytoplasmic proteins were separately extracted from the QBC939 cells treated with shCRM-1 as well as the blank and the vector groups. Notably, as shown in Fig. 6 , CRM-1 expression was closely associated with the subcellular location of p27 ${ }^{\mathrm{Kip} 1}$. As CRM-1 was downregulated in Fig. 6A, cytoplasmic $\mathrm{p} 27^{\mathrm{Kip} 1}$ was also decreased whereas nuclear $\mathrm{p} 27^{\mathrm{Kip} 1}$ was increased in the QBC939 cells. Thus, it is quite probable that CRM-1 may induce the progression of cholangiocarcinoma by regulating the subcellular distribution of $\mathrm{p} 27^{\mathrm{Kip} 1}$. However, further experiments examining point mutations in the phosphorylation sites of $\mathrm{p} 27^{\mathrm{Kip} 1}$ are warranted.

\section{Discussion}

$\mathrm{p} 27^{\mathrm{Kip} 1}$ is a newly discovered tumor suppressor gene that is involved in the negative regulation of cell cycle progression at the G1/S checkpoint. The aberrant expression or localization of 
A
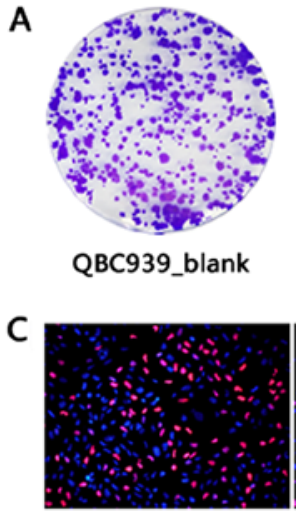

QBC939_blank

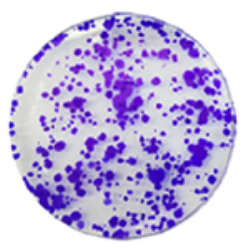

QBC939_vector

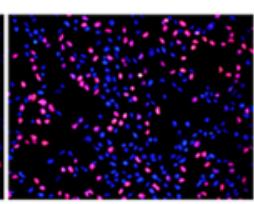

QBC939_vector

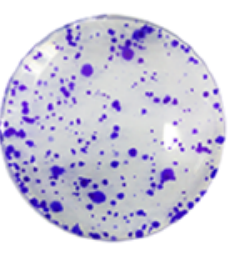

QBC939_shCRM1

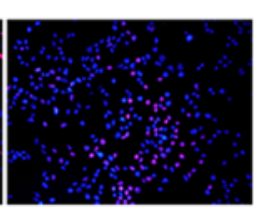

QBC939_shCRM1

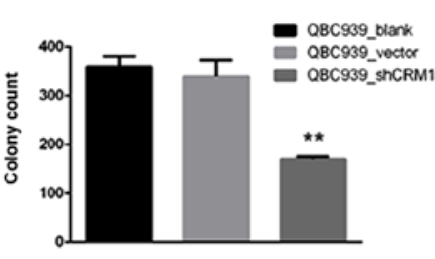

- OBC999_blank - OBC939_vector

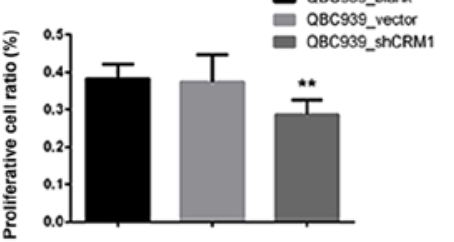

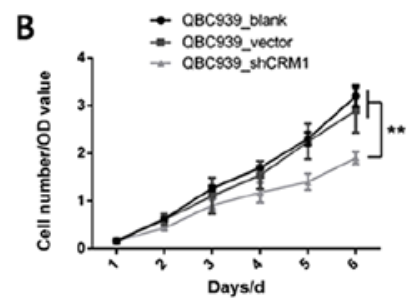

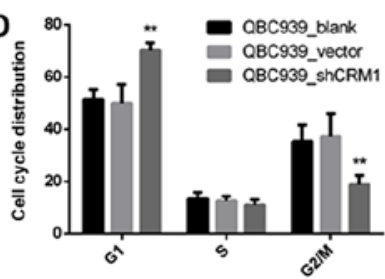

Figure 4. Downregulation of chromosome region maintenance 1 (CRM-1) inhibits the colony forming ability and reduces the viability of the cholangiocarcinoma QBC939 cells in vitro. (A) Colony formation assay demonstrated that the downregulation of CRM-1 decreases the colony forming ability of QBC939 cells. (B) Cell viability assay using a cell counting kit (CCK-8) demonstrated that CRM-1 downregulation reduces the viability of QBC939 cells. (C) Assessment of cell viability using the 5-ethynyl-2'-deoxyuridine (EdU) assay obtained similar results. The red cells are in the proliferation stage whereas the blue cells are the whole population $\left({ }^{* *} \mathrm{P}<0.01\right)$. (D) Cell cycle analysis of all three groups by propidium iodide (PI) staining. ${ }^{* *} \mathrm{P}<0.01$ vs. blank group and vector group.

A

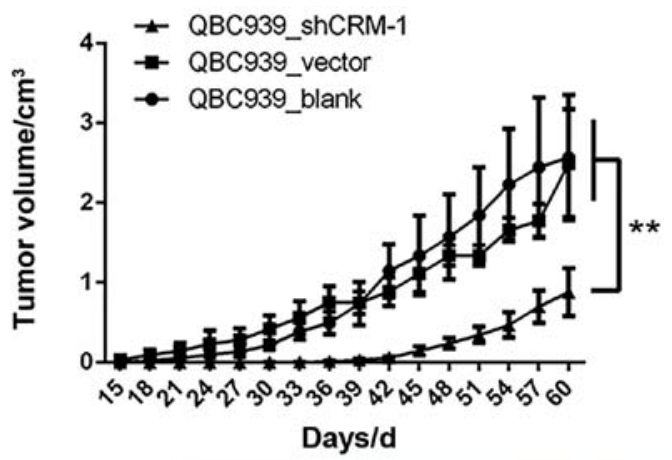

C

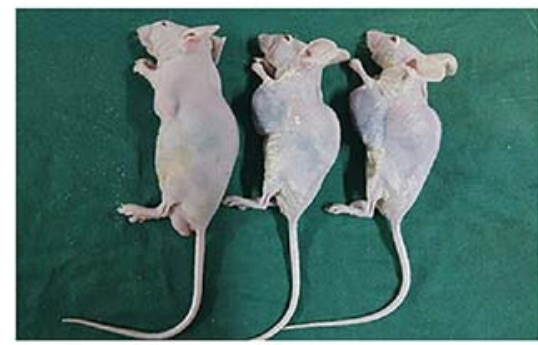

$$
\begin{array}{r}
\text { QBC939_blank } \\
\text { QBC939_vector } \\
\text { QBC939_shCRM-1 }
\end{array}
$$

B
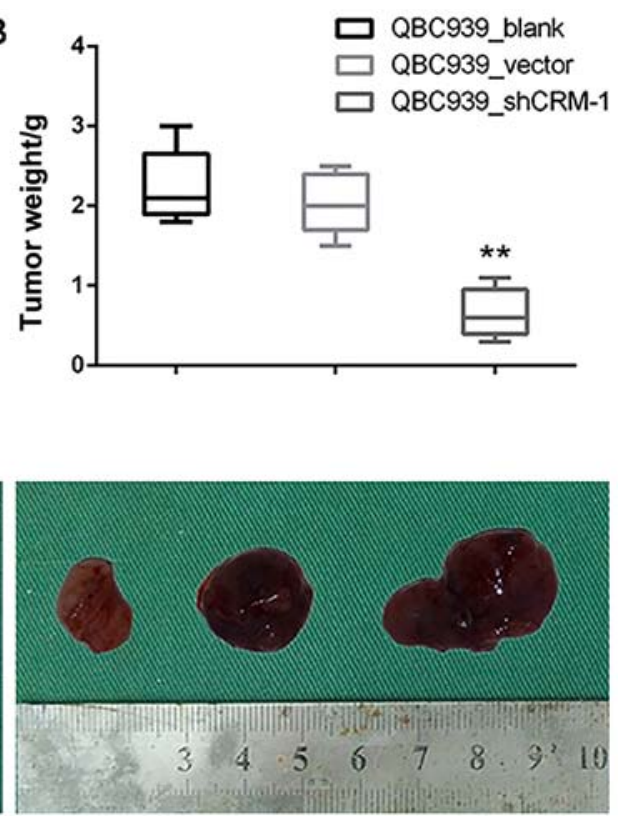

$-\quad-\quad+$

$-+\quad+$

$+$

Figure 5. Downregulation of chromosome region maintenance 1 (CRM-1) inhibits the proliferation of cholangiocarcinoma QBC939 cells in vivo. (A) The tumor growth curve of QBC939 cells injected subcutaneously into the axilla of nude mice demonstrates the inhibitory effect on the proliferation of QBC939 cells following CRM-1 knockdown. ${ }^{* *} \mathrm{P}<0.01$. (B) Tumor weight analysis after sacrifice indicating that the tumor weight is markedly less in the shCRM-1 group than in the blank and vector groups. ${ }^{* *} \mathrm{P}<0.01$ vs. blank group and vector group. (C) Representative pictures illustrating that the tumors formed by QBC939_shCRM-1 are smaller than those in the blank and vector groups.

$\mathrm{p} 27^{\mathrm{Kip} 1}$ weakens its inhibitory effect on the cell cycle, leading to uncontrolled cell growth and carcinogenesis (8). The downregulation and abnormal subcellular localization of $\mathrm{p} 27^{\mathrm{Kipl}}$ have been reported in a number of types of tumor including nasopharyngeal carcinoma (9). Consistent with these previous findings, we found that $\mathrm{p} 27^{\mathrm{Kip} 1}$ expression was decreased in the cholangiocarcinoma tissues compared with that in the chronic cholangitis tissues, suggesting that the aberrant expression of $\mathrm{p} 27^{\mathrm{Kipl}}$ may be associated with the development and progression of cholangiocarcinoma. Immunohistochemistry and western blot analysis showed that the protein expression of $\mathrm{p} 27^{\mathrm{Kip} 1}$ increased sequentially from well- to poorly-differentiated tumors, and from stage I-II cases of cholangiocarcinoma to stage III-IV cases. In addition, the cytoplasmic staining patterns indicated that $\mathrm{p} 27^{\mathrm{Kip} 1}$ was primarily located in the cytoplasm of tissues from poorly-differentiated tumors and those from patients with advanced stage disease. These findings suggested that that there may be an association between the aberrant 
A
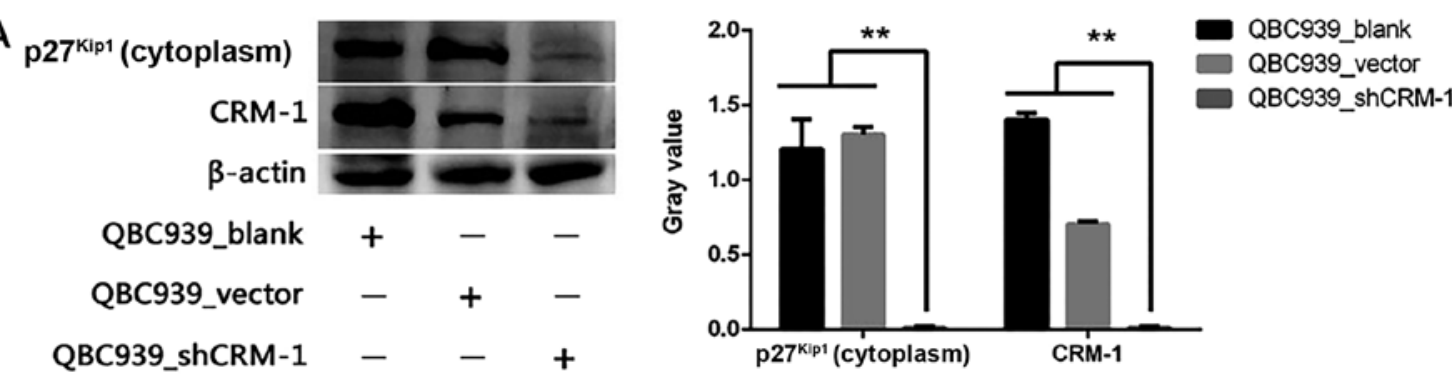

B
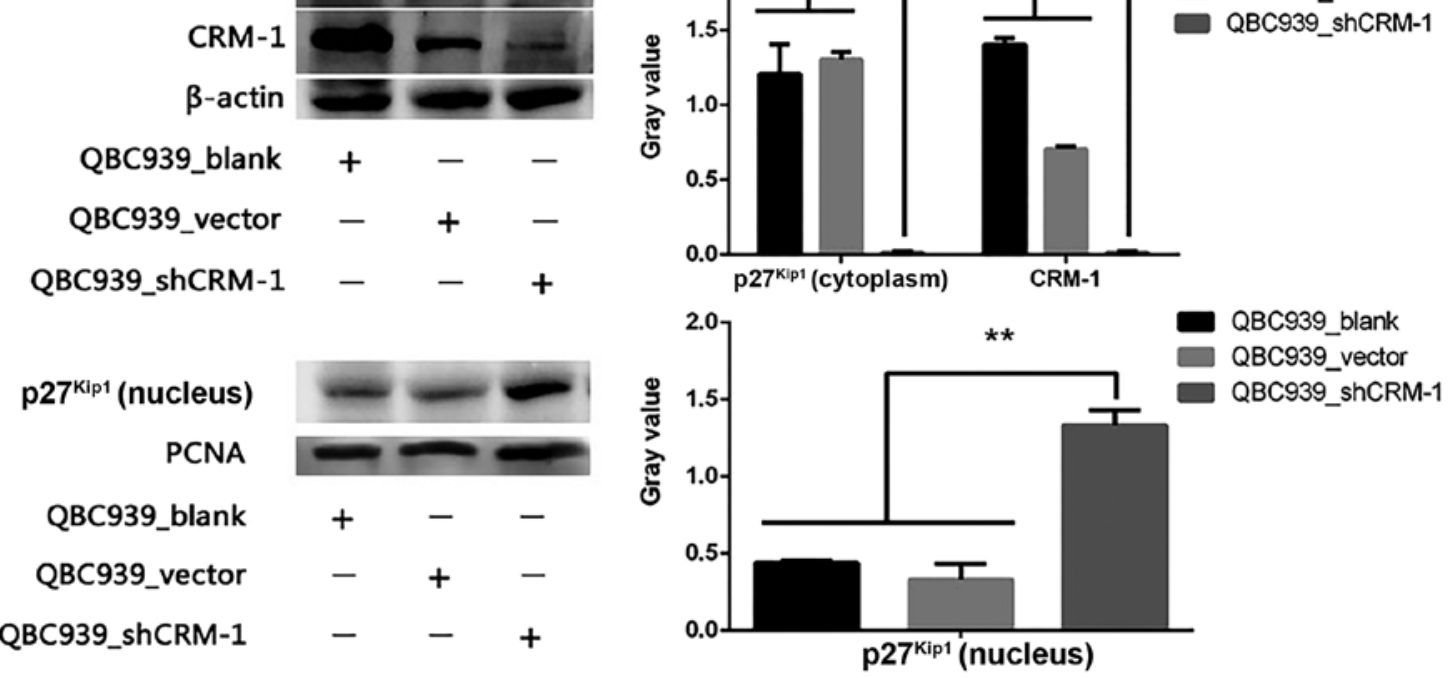

Figure 6. Downregulation of chromosome region maintenance 1 (CRM-1) enhances nuclear p27 ${ }^{\text {Kipl }}$ expression and decreases cytoplasmic p27 $7^{\text {Kipl }}$ expression simultaneously. The cytoplasmic and nuclear proteins were separately extracted from QBC939 cells and (A) p27 ${ }^{\mathrm{Kip} 1}$ protein expression in the cytoplasm was markedly decreased after CRM-1 knockdown whereas (B) p2 $7^{\text {Kipl }}$ expression in the nucleus was markedly increased as compared with the blank and vector groups. ${ }^{* *} \mathrm{P}<0.01$.

expression of $\mathrm{p} 27^{\mathrm{Kip} 1}$ and the malignancy and clinical stage of cholangiocarcinoma, and that $\mathrm{p} 27^{\mathrm{Kip} 1}$ is transported from the nucleus to the cytoplasm during tumor progression in cholangiocarcinoma. Similar observations have been reported in other types of cancer; $\mathrm{p} 27^{\mathrm{Kip} 1}$ expression was decreased in liver cancer tissues compared with that in para-carcinomatous tissues and normal liver tissues, and the cytoplasmic localization of p $27^{\mathrm{Kip} 1}$ closely correlated with malignant progression, clinical stage and invasion in liver cancer (10). In colorectal cancer, the cytoplasmic expression of $\mathrm{p} 27^{\mathrm{Kip} 1}$ was found to be significantly higher in tumor cells compared with that in normal mucosal cells (11). The cytoplasmic localization of $\mathrm{p} 27^{\mathrm{Kip} 1}$ has also been reported to be significantly associated with poor prognosis in ovarian cancer (12). Taken together, these findings suggest that abnormal subcellular localization and increased cytoplasmic expression of $\mathrm{p} 27^{\mathrm{Kip} 1}$ may play an important role in tumor development. However, the mechanisms that regulate $\mathrm{p} 27^{\mathrm{Kip} 1}$ expression and intracellular transport remain poorly understood.

The subcellular localization of a protein is closely associated with its function. A recent proposal for a $\mathrm{p} 27^{\mathrm{Kip} 1}$-regulated subcellular regionalization mechanism suggested that the abnormal cytoplasmic localization of $\mathrm{p} 27^{\mathrm{Kip} 1}$ may separate $\mathrm{p} 27^{\mathrm{Kip} 1}$ from its nuclear effectors leading to its deactivation (13). The majority of studies on the abnormal subcellular localization of $\mathrm{p} 27^{\mathrm{Kip} 1}$ have focused on ubiquitin-degradation pathways. These include a cytoplasmic pathway which is dependent on nuclear translocation through the conjugation of ubiquitin with cytoplasmic ubiquitin ligase KPC (17), and a nuclear pathway dependent on ubiquitin ligase SCF-Skp2 (14). The cytoplasmic pathway is mediated by p-p27 ${ }^{\mathrm{Kip} 1}$ (Ser10) (15), whereas the nuclear pathway is mediated by p-p27 ${ }^{\mathrm{Kip} 1}$ (Thr187). A previous study by our group has confirmed that the nuclear ubiquitin-degradation pathway involving SCF-Skp2 and $\mathrm{p}-\mathrm{p} 27^{\mathrm{Kip} 1}$ (Thr187) was enhanced in cholangiocarcinoma tissues and cells (16). This may be associated with the observed decrease in the nuclear expression of $\mathrm{p} 27^{\mathrm{Kip} 1}$. However, the precise details regarding the association between decreasing nuclear expression and increasing cytoplasmic expression remain unclear. Further investigations in vitro may confirm whether the two pathways co-exist in cholangiocarcinoma. In addition, the association between the translocation of $\mathrm{p} 27^{\mathrm{Kip} 1}$ and the cytoplasmic ubiquitin-degradation pathway involving KPC remains to be determined.

CRM-1 mediates the nuclear export of $\mathrm{p} 27^{\mathrm{Kip} 1}$ by binding to $\mathrm{p} 27^{\mathrm{Kip} 1}$ through a nuclear export signal in a leptomycin B-sensitive manner (17). The nuclear export of $\mathrm{p} 27^{\mathrm{Kip} 1}$ correlates with the phosphorylation of Ser10, and reports have shown that CRM-1 specifically recognizes and binds to Ser10 phosphorylated $\mathrm{p} 27^{\mathrm{Kip} 1}$, thereby promoting its nuclear export (18). Mutation at this site has been shown to cause $\mathrm{p} 27^{\mathrm{Kip} 1}$ to lose its nuclear export capability (19), indicating that Ser10 phosphorylation may play a critical role in the subcellular distribution and functional status of $\mathrm{p} 27^{\mathrm{Kip} 1}$. We found that CRM-1 and p-p27 ${ }^{\mathrm{Kip} 1}$ (Ser10) were highly expressed in the cholangiocarcinoma tissues, and their nuclear expression levels increased with increasing malignancy compared with those in the control samples $(\mathrm{P}<0.05)$. This is consistent with previous findings in neuroglioma which demonstrated that high expression levels of CRM-1 and p27 ${ }^{\mathrm{Kip} 1}$ closely correlated with malignancy, and that high CRM-1 expression was associated with a poor prognosis $(20,21)$. Our results demonstrated that the nuclear expression of CRM-1 and p-p27 ${ }^{\mathrm{Kip} 1}$ (Ser10) inversely correlated with nuclear expression of $\mathrm{p} 27^{\mathrm{Kip} 1}$ and that CRM-1 expression positively correlated with that of p-p27 ${ }^{\mathrm{Kip} 1}$ (Ser10) in the cholangiocarcinoma tissues, which was consistent with the role of CRM-1 in the nuclear export of $\mathrm{p} 27^{\mathrm{Kip} 1}$ in these tumors. Although the nuclear expression of CRM-1 and p27 ${ }^{\text {Kipl }}$ (Ser10) were found to be associated with the degree of malignancy and clinical stage in cholangiocarcinoma, we observed little change in the cytoplasmic levels of these proteins.

The aberrant expression of $\mathrm{p} 27^{\mathrm{Kip} 1}$ may result in abnormal cytoplasmic proteolysis coupled with nuclear translocation 
in cholangiocarcinoma. Our findings suggest that CRM-1 may play a role in the nuclear and cytoplasmic distribution of $\mathrm{p} 27^{\mathrm{Kipl}}$ by recognizing and binding to $\mathrm{p}-\mathrm{p} 27^{\mathrm{Kip1}}$ (Ser10) and thereby regulating the nuclear export of $\mathrm{p} 27^{\mathrm{Kip} 1}$.

Previous studies have demonstrated that specific agents may restore $\mathrm{p} 27^{\mathrm{Kip} 1}$ expression in cells including cholangiocarcinoma cells and trophoblast cells (22-25). The control of protein localization by inhibiting the translocation of $\mathrm{p} 27^{\mathrm{Kipl}}$ has also been applied in cancer therapies (26).

Taken together, these findings indicate that changes in the expression levels and subcellular distributions of CRM-1, p2 $7^{\text {Kip1 }}$ and p-p27 $7^{\text {Kip1 }}$ (Ser10) proteins may be a potential predictor and indicator of malignancy in cholangiocarcinoma. Although further investigations are warranted in order to determine the precise details of how these proteins interact in cholangiocarcinoma, our findings suggest that these proteins may prove to be promising novel targets in the diagnosis, treatment and prognosis of cholangiocarcinoma.

In conclusion, the knockdown of CRM-1 may lead to decreases in p2 $7^{\mathrm{Kipl}}$ levels in the cytoplasm, thereby inhibiting malignant transformation in cholangiocarcinoma. These findings have revealed potentially potent targets for the diagnosis, and prognosis of cholangiocarcinoma which may also serve as novel therapies for the treatment of patients with cholangiocarcinoma.

\section{Acknowledgements}

We thank all the donors who participated in this program and all our coworkers who contributed to this study. The present study was supported by the Natural Science Foundation of Hubei Province of China (project no. 2013CKB020).

\section{References}

1. Duncan TJ, Al-Attar A, Rolland P, Harper S, Spendlove I and Durrant LG: Cytoplasmic p27 expression is an independent prognostic factor in ovarian cancer. Int J Gynecol Pathol 29: 8-18, 2010.

2. Sgambato A, Camerini A, Genovese G, De Luca F, Viacava P, Migaldi M, Boninsegna A, Cecchi M, Sepich CA, Rossi G, et al: Loss of nuclear p27 ${ }^{\mathrm{Kipl}}$ ) and $\alpha$-dystroglycan is a frequent event and is a strong predictor of poor outcome in renal cell carcinoma. Cancer Sci 101: 2080-2086, 2010.

3. Tomoda K, Kubota Y and Kato J: Degradation of the cyclin-dependent-kinase inhibitor $\mathrm{p} 27 \mathrm{Kip} 1$ is instigated by Jab1. Nature 398 160-165, 1999.

4. Smitherman M, Lee K, Swanger J, Kapur R and Clurman BE: Characterization and targeted disruption of murine Nup50, a p27(Kip1)-interacting component of the nuclear pore complex. Mol Cell Biol 20: 5631-5642, 2000.

5. Connor MK, Kotchetkov R, Cariou S, Resch A, Lupetti R, Beniston RG, Melchior F, Hengst L and Slingerland JM: CRM1/Ran-mediated nuclear export of p27(Kip1) involves a nuclear export signal and links p27 export and proteolysis. Mol Biol Cell 14: 201-213, 2003.

6. Ganeshan D, Moron FE and Szklaruk J: Extrahepatic biliary cancer: new staging classification. World J Radiol 4: 345-352, 2012.

7. Jang JY, Kim SW, Park DJ, Ahn YJ, Yoon YS, Choi MG, Suh KS, Lee KU and Park YH: Actual long-term outcome of extrahepatic bile duct cancer after surgical resection. Ann Surg 241: 77-84, 2005.

8. Wang Y, Wang Y, Xiang J, Ji F, Deng Y, Tang C, Yang S, Xi Q, Liu R and Di W: Knockdown of CRM1 inhibits the nuclear export of $\mathrm{p} 27(\mathrm{Kip} 1)$ phosphorylated at serine 10 and plays a role in the pathogenesis of epithelial ovarian cancer. Cancer Lett 343 6-13, 2014.
9. Pan Y, Zhang Q, Tian L, Wang X, Fan X, Zhang H, Claret FX and Yang H: Jab1/CSN5 negatively regulates p27 and plays a role in the pathogenesis of nasopharyngeal carcinoma. Cancer Res 72: 1890-1900, 2012.

10. Dai L, Liu Y, Liu J, Wen X, Xu Z, Wang Z, Sun H, Tang S, Maguire AR, Quan J, et al: A novel cyclinE/cyclinA-CDK inhibitor targets p27(Kip1) degradation, cell cycle progression and cell survival: implications in cancer therapy. Cancer Lett 333: 103-112, 2013.

11. Ciaparrone M, Yamamoto H, Yao Y, Sgambato A, Cattoretti G, Tomita N, Monden T, Rotterdam H and Weinstein IB: Localization and expression of p27KIP1 in multistage colorectal carcinogenesis. Cancer Res 58: 114-122, 1998.

12. Masciullo V, Ferrandina G, Pucci B, Fanfani F, Lovergine S, Palazzo J, Zannoni G, Mancuso S, Scambia G and Giordano A: p27Kip1 expression is associated with clinical outcome in advanced epithelial ovarian cancer: multivariate analysis. Clin Cancer Res 6: 4816-4822, 2000.

13. Ibañez IL, Bracalente C, Notcovich C, Tropper I, Molinari BL, Policastro LL and Durán H: Phosphorylation and subcellular localization of $\mathrm{p} 27 \mathrm{Kip} 1$ regulated by hydrogen peroxide modulation in cancer cells. PLoS One 7: e44502, 2012.

14. Tsvetkov LM, Yeh KH, Lee SJ, Sun H and Zhang H: p27(Kip1) ubiquitination and degradation is regulated by the $\mathrm{SCF}(\mathrm{Skp} 2)$ complex through phosphorylated Thr187 in p27. Curr Biol 9: 661-664, 1999.

15. Kazi A, Carie A, Blaskovich MA, Bucher C, Thai V, Moulder S, Peng H, Carrico D, Pusateri E, Pledger WJ, et al: Blockade of protein geranylgeranylation inhibits Cdk2-dependent p27Kip1 phosphorylation on Thr187 and accumulates p27Kip1 in the nucleus: implications for breast cancer therapy. Mol Cell Biol 29: 2254-2263, 2009.

16. Luo J, Chen YJ, Wang WY and Zou SQ: Effect of mutant p27(kipl) gene on human cholangiocarcinoma cell line, QBC(939). World J Gastroenterol 14: 5344-5348, 2008.

17. Kamura T, Hara T, Matsumoto M, Ishida N, Okumura F, Hatakeyama S, Yoshida M, Nakayama K and Nakayama KI: Cytoplasmic ubiquitin ligase KPC regulates proteolysis of p27(Kip1) at G1 phase. Nat Cell Biol 6: 1229-1235, 2004.

18. Kotoshiba $S$ and Nakayama K: The degradation of $\mathrm{p} 27$ and cancer. Nihon Rinsho 63: 2047-2056, 2005 (In Japanese).

19. Lee JG, Song JS, Smith RE and Kay EP: Human corneal endothelial cells employ phosphorylation of p27(Kip1) at both Ser10 and Thr187 sites for FGF-2-mediated cell proliferation via PI3-kinase. Invest Ophthalmol Vis Sci 52: 8216-8223, 2011.

20. Rodier G, Montagnoli A, Di Marcotullio L, Coulombe P, Draetta GF, Pagano M and Meloche S: p27 cytoplasmic localization is regulated by phosphorylation on Ser10 and is not a prerequisite for its proteolysis. EMBO J 20: 6672-6682, 2001

21. Shen A, Wang Y, Zhao Y, Zou L, Sun L and Cheng C: Expression of CRM1 in human gliomas and its significance in $\mathrm{p} 27$ expression and clinical prognosis. Neurosurgery 65: 153-160, 2009.

22. He W, Wang B, Zhuang Y, Shao D, Sun K and Chen J: Berberine inhibits growth and induces G1 arrest and apoptosis in human cholangiocarcinoma QBC939 cells. J Pharmacol Sci 119: 341-348, 2012.

23. Huether A, Höpfner M, Baradari V, Schuppan D and Scherübl H: Sorafenib alone or as combination therapy for growth control of cholangiocarcinoma. Biochem Pharmacol 73: 1308-1317, 2007.

24. Kotake Y, Nakayama K, Ishida N and Nakayama KI: Role of serine 10 phosphorylation in p27 stabilization revealed by analysis of p27 knock-in mice harboring a serine 10 mutation. $\mathrm{J}$ Biol Chem 280: 1095-1102, 2005.

25. Nadeem L, Brkic J, Chen YF, Bui T, Munir S and Peng C: Cytoplasmic mislocalization of p27 and CDK 2 mediates the anti-migratory and anti-proliferative effects of Nodal in human trophoblast cells. J Cell Sci 126: 445-453, 2013.

26. Shiraso S, Katayose Y, Yamamoto K, Mizuma M, Yabuuchi S, Oda A, Rikiyama T, Onogawa T, Yoshida H, Hayashi H, et al: Overexpression of adenovirus-mediated $\mathrm{p} 27^{\mathrm{Kipl}}$ lacking the Jab1binding region enhances cytotoxicity and inhibits xenografted human cholangiocarcinoma growth. Anticancer Res 29: 20152024, 2009 . 